\title{
TUSSOCK GRASSLAND : MARGINAL LAND
}

\author{
By R. K. IRELAND
}

The real problem before this and similar conferences is to emphasise to the farmers of New Zealand the urgency of increasing production and to bring inspiration to the farmer by advice, demonstration, and assistance.

I venture to suggest that it should be done in logical stages, and we have an outstanding and practical example of what has been done at Home in the last 14 years. There, at the commencement of the Second World War local committees of farmers were appointed to that end. It was first carried into effect by war regulations, it culminated in the Agriculture Act of 1947, and is still being progressively administered on the same plan. It was commenced under a National Government, it was carried on by a Labour Government, and is now being pressed on by a Conservative Government, and in fact in the Old Country farming has been elevated above party politics, just as it should be here, to the lasting benefit of the Dominion's economy as a whole.

The first thing required in New Zealand is, I suggest, the taking of a census of farms and farmers (as was done in England in 1941-43 and the report published in 1946). From these figures could be ascertained the direction of the next step to take. In England this report showed that over half of the farmers were producing 80 per cent and over of the reasonable productive capacity of their farms (A grade), one third were producing from 60 per cent to 80 per cent (B grade), and some were producing less than 60 per cent of the farm's capacity (C grade). The job of the local committees is to advise and assist the B grade farmer to step up into the A grade, and also to try to assist the $\mathrm{C}$ grade man out of his difficulties, because it is largely from the $B$ and $C$ grade farmers that the increase in primary production will be achieved.

That in New Zealand we are lagging behind in our duty to produce the maximum from the land is 
obvious from the latest statistics of the volume of farm production. N.Z. farm production increased only 10 per cent. from 1941 to 1951 . It is volume. that is the real standard, because the value figure is completely distorted by the inflation in our currency.

There is no record in New Zealand to show how many efficient farmers we have, but to give you some idea of our production I will quote Bruce Levy reported in the "Press" in September:-

"Less than a third of New Zealand's improved ploughable land was effectively farmed, another third of ploughable land was at a low, mediocre level, and the remaining third was definitely not pulling its weight. If it were fully developed, we could easily double the present production."

There may be some criticism by New Zealand farmers of the British scheme, but it works and has worked for a number of years under three Governments, presumably with the support of the farmers of Great Britain. On Mr Churchill's statement, they are producing sufficient to support two-thirds of their 50 million population.

New Zealand, of about the same size, is not producing to a comparable extent. Probably we never will because of our soil conditions, But if we are to continue as a welfare State and carry the increases of Social Security, etc., we must produce more, employ more, and export more.

The marginal lands of New Zealand, an enormous area of 14 million acres, with a progressive scheme similar to that in Great Britain would increase by millions of pounds the production we have today.

I am not referring to the mountainous country of over $3000 \mathrm{ft}$. The mountainous area amounts to over 23 million acres, and though stock is carried on many parts of it, this mountainous area is outside the scope of my paper.

I would refer to the lowland country of 18 million acres on which most of you farm, and possibly you do it very well. Think what it was when the moa stalked over it, and what it was when our forefathers started to break it in. It was made by those early settlers and we are reaping the benefit, and we are satisfied, possibly too well satisfied. Yet there are 14 million acres of marginal land yet to be broken in. It will not be easy, but neither was the task of the early settlers easy when they broke in the lower lands of Canterbury.

Some settlers on the marginal lands are produc- 
ing reasonably well and they and their employees are the type that should be encouraged and helped. The marginal lands of Canterbury and Otago require a type that will stay and farm. The weather conditions in winter are difficult, with severe frosts, snow, and isolation. I have farmed among these people in this back country for about 30 years and have the greatest admiration for them. They and- their families should be encouraged to stay.

This marginal country has' been criticised and damned. 'Admittedly there are 'rabbits; there has been too much burning and over-stocking and tussock grub. But look at the area-14 million acres. Are we New Zealanders going to fold our arms and say. it is waste country and not worth bothering about? I will give my own experience farming such country.

In 1924 I bought a Government leasehold property of 18,000 acres called "Ribbonwood" in the Omarama district. It is about 50 miles west of Kurow and about 8 miles from Lake Ohau, with a rainfall of about 25 in. Height above sea, level varies from 2000 to $5600 \mathrm{ft}$. It carried about 4300 half-bred wethers. The routine was each year to sell the old and buy young wethers. My first wool clip was 89 bales. I was not satisfied with this and decided to run a Merino ewe flock. I had to fence the winter country from the summer, as the block was just ring fenced with no dividing fences. The wethers lived on the warmer country. The back faces had to be burned. At my first shearing of ewes the lambs were turned on to tussock that had been well eaten over. There was nothing better. The lambs got a bad check and I decided that if. I could not do better, I would sell the property. I ploughed 25 acres of tussock, though I was advised not to. The statement was that I would not have even tussock in the finish. However, 'after 2 years, I had a fair paddock of grass (all netted) to put the lambs on at shearing. That seems easy today, but at that time I had to go against the strong opinion of the settlers in the district. From this time onwards I ploughed and fenced a paddock, each year. I tried a double-furrow plough similar to down-country ploughs, but this was too light. I later used a swamp plough with horses on contract. Later still I had my own tractor with a single-furrow swamp plough. The country is rough,. with not only stones, but boulders. I still use the single swamp plough for this class of country.. I plough in the autumn, work in spring, and sow grass in November and December. 


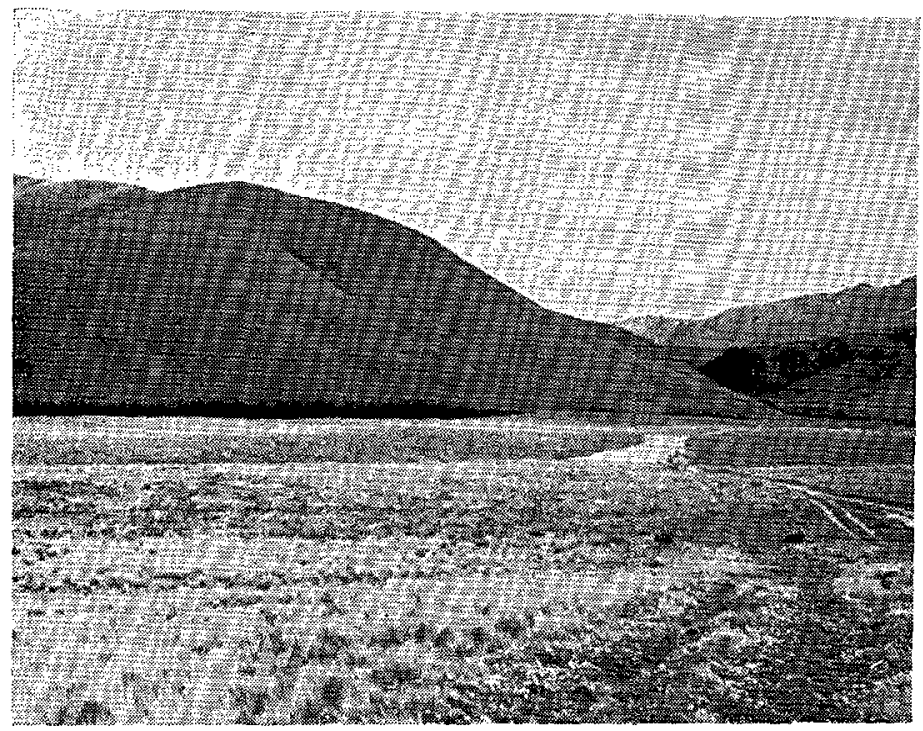

An area of hard tussock (Festuca nozaerelandiae) at "Ribbonwood" in the Omarama district, oversown with clovers, Note the fine establishment of white clover in the foreground.

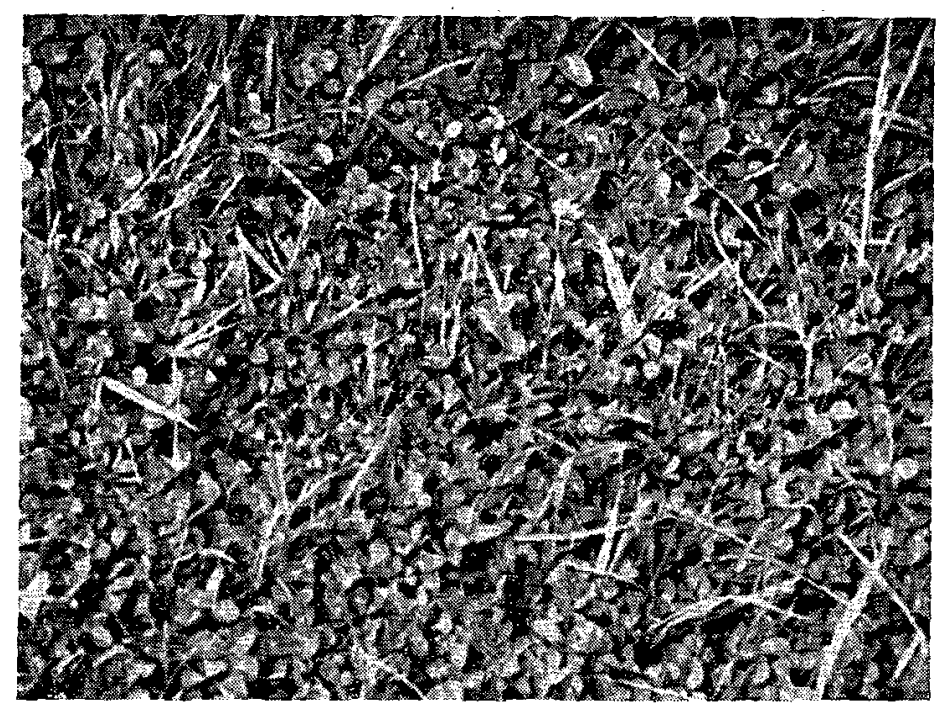

A elose-up of an improved pasture on "Kibbonwood." The pasture is white clover dominant with some cocksfoot and crested doustail. 
I now have approximately 1500 acres in grass and cloyers and all the fences are rabbit-netted. I sow with superphosphate a mixture of $10 \mathrm{lb}$. of perennial ryegrass, 10lb. of cocksfoot, some crested dogstail, timothy, Mlnntgomery and white clover-clover suits this country. The ryegrass does not last, but the cocksfoot and clovers make a good pasture ; some pastures have been down for 20 years. In breaking up pasture I sow oats for chaff for winter feed. Oats do well and I always have plenty of chaff. Lucerne does well after grass. Frost lift is very severe, particularly on young grass paddocks. This is efficiently dealt with by rolling in the spring with a 6-ton roller, built in three sections. I get better results by drilling the seed rather than by broadcasting.

Some of the flat country is too rough with stones and boulders to plough. About 500 acres of this have been topdressed with 1 ton of lime and 2cwt. of superphosphate and about $61 \mathrm{bs}$. of clover per acre. The clover, Montgomery, suckling and white are mixed through the superphosphate and sown through the spin topdresser. Clover seed strikes well in this way. Grass has been tried, but is not very successful.

Aerial topdressing on the hills has been tried with 2cwt. of superphosphate and $61 \mathrm{bs}$ of clover per acre. The. first sowing was done early, in May. The ground was frozen and with no prospect of a strike until spring, but the theory was that clover contains an oily substance that preserves it. There was a good strike of clover among the tussock in October/November and in the following year the hillside of approximately 1000 acres, was white with clover in flower and in the autumn the heads were full of seed. This area is between 2000 and 3000ft. above sea level.

In the spring last year, a further 2000 acres were sown by plane in a similar way. The planes had to rise over a saddle $3500 \mathrm{ft}$. high with $3 \mathrm{cwt}$. of superphosphate. It was not easy and it was a credit to the airmen. The clover struck and it is hoped will make a good showing this summer. The disadvantage of this system is that clover dies down in the winter: Grass would be a great advantage, but though cocksfoot and crested dogstail have been tried, they were not very successful. My search today is for a grass that will establish reasonably well in tussock when sown by air with clover.

Each year, with the increase in grass in the paddocks, I increased the number of stock carried; 6,300 
Merino sheep are now shorn and 140 head of cattle are carried compared with 4300 sheep and no cattle when I purchased this property. The wool clip has increased from 89 to 180 bales.

The sheep routine is to hold 2500 ewes in the paddocks with the rams in May and June. There is usually sufficient grass to carry them without artificial feed. At the end of June the ewes are turned on to the hills. These hills are not grazed during the seeding season. The sheep stay there until early September when they are brought into the paddocks and fed with hay and chaff until early October. By this time there is sufficient green feed and the ewes leave the dry feed. Lambing starts about October 5; the percentage is about 70 per cent. We sometimes get snow in October and this knocks the lambing percentage. About 500 ewes are mated with Romney rams and the percentage from these ewes is higher than from Merino, about 80 per cent. The half-bred lambs are sold as ram lambs or ewe lambs ; no halfbreds are carried over. The ewes and lambs stay in the paddocks until the lambs are weaned. The ewes then go on to the hills and stay there until they come in again for tupping. Under this system both the hills and the paddocks get a periodical spelling.

The cattle are Hereford cows mated to stud Aberdeen Angus bulls. Last year 90 cows produced ' 70 calves. This year we have 100 cows to calve and this summer we will have 130 cows to the bull. The cows are mated in paddocks. After the calves are weaned the cows go on the hills without artificial feed. They come into the paddocks in October; some calve on the hills. They stay in the paddocks until the calves are weaned. All the calves are sold. The cattle eat rough stuff in gullies and swamps and make them suitable for sheep. No tussocks are burnt.

On, this property the main return is from wool. To increase the weight of wool per sheep they must have sufficient feed every month of the year. Our aim, therefore, is to keep the wool growing without a break. The increase in 30 years is from $61 \mathrm{bs}$. per grown sheep to $9 \frac{1}{4}$ lbs. (ewes, wethers, rams). Hoggets produce $61 \mathrm{bs}$. Thirty acres of oats and also lucerne are grown for sheep feed. Considerably more sheep could be carried in the summer, but winter feed is the limiting factor.

To make use of the surplus summer grass, last year we made about 300 tans of silage. As we had 
sufficient chaff and hay, this silage was not used, but may be useful yet.

Strong nor-westers are the prevailing winds and to give shelter to the paddocks and stock plantations of trees are grown, some over a mile in length with 6 rows of trees. Over 50,000 trees are growing, the early plantations being $60 \mathrm{ft}^{-}$. high. In the early days firewood was carted a distance of 50 miles from Kurow. Now there is any amount of firewood from plantations which are being thinned.

The varieties grown are Pinus insignis, ponderosa, murrayana, laricio, oregon and larch. All do well. Self-sown seedlings from these trees are now growing in the tussock.

This is a very brief summary of the improvements made, but I will be very pleased for anyone to visit the property and inspect for himself. I am one of many who has made improvements on this marginal country, but there is a vast area waiting to be tackled, and it takes a great amount of capital and labour to make these improvements. If I have interested you by reciting my experiences with "Ribbonwood," what is the next step towards a general improvement?

The Sheep Commission did good work in impressing the Government that improvement could be made. The result of this was the passing of the Marginal Lands Act in 1950.

A board has been appointed under this Act with power to appoint committees in each district.

The principle is quite good, provided live men are appointed to the committees in each district. I am strongly in favour of farmers' Committees and giving them wide responsibility. The Rabbit Board Committees are a successful example of this.

If the Marginal Land Board assumes too much control, the scheme is doomed to failure. Local knowledge and local control are necessary to make it a success.

Further, considerable latitude must be given to committees in lending money to settlers. It is no use starting if every advance has to be fully secured.

This is marginal country. Experiments will require to be made with aerial topdressing, irrigation, surface sowing, second growth, fencing, and in other ways. It is the farmer who will make these experiments on his own land. Some of these efforts may not be a success and therefore the Marginal Lands Board should lose, not the farmer. Assistance should be 143 
given in the form' of subsidising the farmer's own expenditure as it is now the practice for shelter belts of trees, The Board should have ample reserves to work on. My idea is that the Government should advance to the Marginal Lands Board 55 million. The farmers' reserve funds from wool and meat should also provide another $£ 5$ million. You may think I have lost my head in talking in millions, but if so, you may not have realised the stupendous task that is involved. If the Act is to get anywhere, it has to deal with 14 million acres of land, much of which cannot bring increased results for a good many years, and none of it without a large capital expenditure. Great Britain's latest objective is to reach 160 per cent of prewar volume of output by 1956. She encourages output in various ways ; for instance, by paying a subsidy of $£ 5$ per head for every calf grown on hill country. Also she will pay $£ 10$ per acre on land requiring abnormal expense to bring it into a. good state of cultivation. This land, I presume, would be similar to some of New Zealand's marginal country which would be difficult to bring in.

The Economic Society of Australia and N.Z. concluded in Auckland last month stated that farming should have first call on all the country's resources in the future economic development of New Zealand. $\mathrm{Mr}$ G. A. Holmes, Superintendent of Invermay Research Station, is reported as follows: "There are vast areas of country today in a far worse condition than when the white man took over. There are millions of acres of second-class land in the South Island which should be improved." William Davies in his book states: "Some day, of course, the pressure for food will be great enough to force Britain to develop her marginal lands. The cost may be large and there is no guarantee that every acre will repay the reclaiming generation."

New Zealand farmers are generally cautious but in this scheme of marginal lands it is necesssary to take a wide view. We cannot get things, done sitting by the fireside and talking to ourselves, neither will we get anywhere by saying the Government should do it. The Government will act, provided they see that the farmers of this country want the marginal lands developed. Get on your big boots, with fire in your eye, talk to Federated Farmers, keep on talking until we get the Marginal Lands Act a live concern. 